\title{
Capturing Iraq: Optical Focalization in Contemporary War Cinematography
}

\author{
Rachel Fox, July 2018
}

\begin{abstract}
This article investigates different registers of embedded and fragmentary focalizations in war cinematography on the Iraq War (2003-2011), focusing primarily on The Hurt Locker (2008) and the HBO mini-series Generation Kill (2008), but also addressing American Sniper (2014) and the Abu Ghraib scandal. I argue that the "extreme close up," that focuses almost unilaterally on the men on the ground during the Iraq War, implicates a "bigger picture": a larger frame of discourse put forward by the corporate media and the government. This is primarily achieved through recursive narrative structures and through the use of diegetic ocular apparatuses, which are embedded onscreen. These renditions of mise en abyme implicate, re-negotiate, and even argue with the wide-angle perspective which frames the Iraq War.
\end{abstract}

\section{Keywords}

Iraq War, fragmentary focalization, $\underline{\text { mise en abyme, }}$ The Hurt Locker, Generation Kill

This article considers cinematographic representations of the Iraq War (2003 - 2011), focusing primarily on Kathryn Bigelow's The Hurt Locker (2008) and the HBO mini-series Generation Kill (2008), which is adapted from Evan Wright's ethnographic book of the same name, alongside Clint Eastwood's American Sniper (2014) and the Abu Ghraib scandal. These cinematographic representations of war are often composed out of a series of "extreme close-ups," or what I will call "fragmentary focalizations.” Engaging which the rhetorical device of focalization as it is represented onscreen — and the bodies that are visually 
captured-I argue that these instances of "extreme close-up" are, in fact, drawn into a "bigger picture," and are implicitly political, fitting within larger frames of discourse, which are put forward by the media and the government.

The world's highest grossing war film since Saving Private Ryan (1998), American

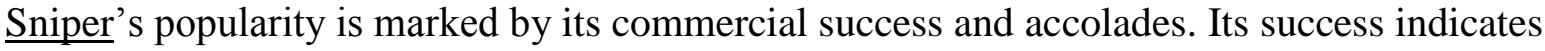
that the Iraq War is something that has come to represent a significant cachet in commercial media. However, despite the much received praise, American Sniper has also been criticized for its apparent failure to offer political commentary. Reviewer, Matt Taibbi (2015), warns that " $[\mathrm{t}]$ he really dangerous part of this film is that it turns into a referendum on the character of a single soldier," Navy SEAL Chris Kyle (Bradley Cooper), rather than on the "Rumsfelds and Cheneys" responsible for the orders given. The focus on a single soldier on the ground, and not on the wider political field presents something of a risk. This apparent narrow, apolitical vision is perhaps further accentuated by Kyle's role as a military sniper. The magnified lens of his weapon's scope opens up the register of an "extreme close-up" and facilitates and directs the act of looking. The act of looking is embedded within these cinematographic representations of the Iraq War, and it is through an examination of how the look is deployed onscreen that I situate the "extreme close-up" within the "bigger picture." In Generation Kill and The Hurt Locker the direction of the look - the focalization - is mediated through a variety of different ocular apparatuses: the cinematographic camera; the viewfinder of a portable video camera; the scope of a weapon; and the screen of a laptop. These optical focalizations are often mechanical or digital and are embedded onscreen as a palimpsest, or mise en abyme. This article explores the direction of the look and the act of watching, and examines how the use of different optical apparatuses is employed onscreen. Further to this, it investigates how these ocular habits and devices work within a larger biopolitical field, wherein the bodies of US soldiers and Iraqi insurgents and civilians are implicated within the 
machinery of war: their interactions mediated and even facilitated by the diegetic optical apparatuses used on the ground and embedded onscreen.

I use focalization as a rhetorical device, in conjunction with the ocular apparatuses that I am considering in The Hurt Locker and Generation Kill. Mieke Bal introduces focalization as that which represents "the relation between the subject and object of perception" $(2012,41)$. Focalization is an action that connects these two points in which the focalizing subject directs their look towards the focalized object (or subject). Bal favours the terminology of focalization over that of "perspective" which she argues is an ambiguous term that has "come to indicate in the tradition of narrative theory both the narrator and the vision" (1997, 143). With narratology forming the basis of Bal's work, she takes a "rhetorical" rather than an "optical" stance, which emphasizes how the scene is conceived, not what it conceives (Bryson, 2001, 8). Bal's conceptualization of focalization serves to indicate "neither a location of the gaze on the picture plane, nor a subject of it, such as either the figure or the viewer. Instead, what becomes visible is the movement of the look $(2012,39)$. In this rhetorical approach it is neither the visualizer (the "location of the gaze"), nor the visualized object (the "subject" of the image) that construes the act of focalization, but rather the relation - the movement—-between, and around, the two points of contact.

In both The Hurt Locker and Generation Kill, fragmentary focalizations construct a picture of the Iraq War onscreen. Optical devices are a huge component of these cinematographic texts, and this article is focused not so much on what is represented onscreen, but rather how the look is deployed and from which direction. I examine the ways in which acts of looking are embedded within recursive narrative structures, and within digital and mechanical apparatuses and frames, through which fragmentary focalizations build a network of connections between focalizer and focalized, agent and subject, watcher and watched. The movement between these supposed binary identifiers (in which sighting is 
privileged over sighted) is often collapsed or compounded as a result of the embedded visual and/or narrative structures. However, it remains that, as signified by American Sniper's dehumanizing treatment of Iraqi's as "savages" and as bodies caught in the crosshairs of the sniper's ocular scope, US operatives are typically positioned in the advantageous position as the focalizing agents. Fragmentary focalizations_embedded, palimpsestic, and mise en abyme-implicate a "bigger picture" and call direct attention to how the face of war is changing in terms of mechanical and digital visualizing apparatuses not just being used to represent the Iraq War onscreen, but also to facilitate that war.

\section{Embedded Focalizations: Recursive Narrative Structures}

Released in 2008, before the "formal" conclusion of the Iraq War, the narratives of The Hurt

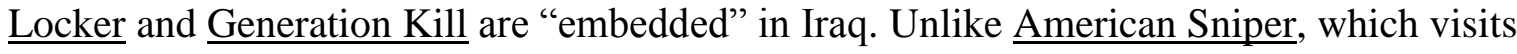
home at regular intervals throughout the film, in The Hurt Locker and Generation Kill the home front is barely screened at all. Both texts are claustrophobic insofar as the narrative is almost completely contained within Iraq and, paradoxically, this claustrophobia is compounded in that (unlike American Sniper) both The Hurt Locker's and Generation Kill's narratives are open-ended. With no end in sight, with the Iraq War still ongoing upon these texts' release, the "extreme close-up" is perpetrated by the inability to present a singular, complete unit, but rather a cyclical, even repetitive, narrative. This is especially noticeable in The Hurt Locker (2008) which begins (following the prologue scene) in media res- "Days Left in Bravo Company's Rotation: 38"-and ends by cycling back to the beginning — "Days Left in Delta Company's Rotation: 365." The film's inter-titles literally counts down, only to begin the cycle again. This resembles what Brian McHale has identified as a recursive structure, which "results when you perform the same operation over and over again, each time operating on the product of the previous operation" $(1987,112)$. 
The recursive structure in The Hurt Locker, illustrated above, is further extenuated by the inability to escape the terrain of war. The protagonist, Sergeant First Class William James (Jeremy Renner), spends all but three and a half minutes of screen time at home. But even at home, the one true break from the recursive structure of the Iraqi landscape, the space depicted is baffling for the returned soldier. The supermarket scene where James struggles to choose cereal from the vast selection available represents a moment of the surreal or, indeed, of simulacrum, and leaves the soldier disassociated from his stateside home. Unlike Generation Kill, which never returns stateside, James is presented with an opportunity to break from the recursive cycle of war, an opportunity that he is ultimately unable to take.

In American Sniper, the film concludes with Kyle's indefinite return home and an honourable discharge. This closure (though followed by Kyle's death in reflection of true-life events) is, to some extent, enabled by the formal closure of the Iraq War before the film's release. In contrast, in both The Hurt Locker and Generation Kill, the end was not yet in sight. In light of postmodernist texts that flaunt recursive structures for their own sake, McHale asks "why stop the recursive operation of nesting worlds within worlds at any particular level of embedding? why stop at all, ever?" (1987, 114-15). His quandary of "why stop" is especially poignant for these two cinematographic texts as, at this point, there is not yet a point at which to stop. This is highlighted in Generation Kill, which recounts the very beginning of the US's entry into Iraq. In the episode, “Stay Frosty" (2008) Corporeal Josh Ray Person (James Ransone) proclaims, upon coming under enemy fire: "What the fuck, man. Don't these fucking guys know that we've won the war already?" In the case of the Iraq War, it was not so much the initial invasion that proved problematic, but rather maintaining occupation after the fact. As Patrick Porter puts it: "Prepared for conventional battles against a clear adversary, surgical invasion and swift, overwhelming strikes, America's military was unprepared for post-invasion disorder in Iraq, and for prolonged contact with complex 
foreign societies" $(2009,8)$. In the final episode, fifteen minutes from the end of the miniseries Lieutenant Nathaniel Fick (Stark Sands) announces: “This war has an official name now. Operation Iraqi Freedom." ("Bomb in the Garden”, 2008). Generation Kill is so far away from the formal end of the war that it has barely begun.

While Generation Kill ends at the beginning, the failure to see an end to the war in The Hurt Locker is marked by the film beginning in media res, and in the fragmentary sections, marked by each inter-title, in which the war comes to represent something of a disassociated and repetitive performance. In some respects, the short segment in which James does return home comes across as even more illusory than the scenes from the "war front": the overbearing bright whiteness in the supermarket scene rather literally casts a spotlight on the scene's oddity. James, the focalizer, looks to both his left and right down the aisle of cereal; the cinematographic camera (indicative of James' look) lingers on the simulacrum of repeatedly uniform and colourful cereal boxes on the shelves. In The Hurt Locker, the camera captures an image of the "war front" that offers a washed out colour palette, which feels starkly empty. At the "home front" the scene feels stark because of the pervading, even aggressive, fullness of colour and branding. The "look" is filled with a different medium at home, one that is equally monotonous and claustrophobic, and one that appears totally out of sync with the palette that viewers have just spent nearly two hours adjusting to. Three and a half minutes is not enough time to readjust to this new register of the "home front." Consequently, the "home front" appears embedded within the discursive and representational frame of the "war front," with its privileged screen time. The frames are inverted, wherein both the scenes from the "war front" and "home front," respectively empty and full, are structures (of no-space or overt-space) that are both implicated as representational and simulated spaces. The brief scenes at the "home front" represents a break from the recursive focalized fragments from the "war front" setting, but, if this marks the end of James' tour, the 
conclusion of the film, which ends with the beginning of James' next foray overseas, represents not just a film that begins, but also ends in media res. By representing an oppositional, but equally simulated, space at home, Bigelow draws even more attention to the representational space that is focalized in fragments overseas. The "home front" is but one more representational fragment. Even here, The Hurt Locker offers only the barest of glances, an "extreme close-up" of home before continuing back to the war in a seemingly infinite, and certainly simulated loop, one which inverts frames and embedded focalizations to insinuate that the "war front" actually composes, or significantly overlaps with what we might constitute as the "bigger picture."

In addition to this recursive model, McHale also explores the use of "nested representations" which appear, for example, as a film-within-a-novel, or a photographwithin-a-film, wherein "the fiction's ontological "horizon" is effectively lost" (1987, 113-14). This nested model, results in "a representation [that] may be embedded within itself, transforming a recursive structure into a structure en abyme" (McHale, 1987, 114). In Generation Kill embedded media is represented by both the digital video camera that is used by a number of soldiers, and edited into an amateur film by Corporal Jason Lilley (Kellan Lutz), and the notepad that is used by the journalist, referred to as "Scribe" or "Rolling Stone" throughout the mini-series. The two formats of recording/reporting represent two significant changes to how information was gathered and disseminated to the public during the Iraq War, with the increased use of portable video cameras being used by soldiers on the ground, and with "the large-scale presence of journalists on the battlefield, embedded in military units" (Tumber and Palmer, 2004, 13). In the mini-series, Generation Kill, the journalist occupies a complex position. The process of "embedding" results in mise en abyme - an image-within-image, a frame-within-frame - which layers and inserts ambiguity into the frame, thus confusing its structure. In the case of the embedded journalist, the 
individual potentially finds themselves in the position of "becoming participants as opposed to observers" (Tumber and Palmer, 2004, 61). In the case of soldiers making amateur videos, this situation is reversed, with participants of war also becoming its observers. The boundaries between the focalizer (the watcher whose point-of-view is presented) and the focalized (the subject being observed) become blurred.

In the HBO mini-series, the direction of focalization, and the relationship between observer and observed, is complicated, whereby both the soldiers and the journalist, Wright, whose written account the mini-series is based off, are both the focalized subjects and the focalizers. The frame of reference between focalizer and focalized is nested; embedded. Bal identifies the act of framing whereby, "in a regress that might, in principle at least, be infinite, the agent of framing is framed in turn. In this way, the attempt to account for one's own acts of framing is doubled" $(2012,135)$. In the cinematographic adaptation of Generation Kill, the representation of the embedded journalist ("Scribe") indicates an embedded narrative-a doubling of focalizer and focalized—of framing and framed. The specific ethnographic account in Generation Kill represents a series of "extreme close-ups" that are nested and layered: a patchwork of overlapping focalizations that are rhetorically witnessed, recounted, adapted, and represented narratively and optically in a collaboration which begins to build a "bigger picture."

\section{Sighting: Scopes, Cameras, and Bodies}

The next two sections of this article examine the effect of diegetic mechanical and digital optical apparatuses. Oftentimes the tools that facilitate the representation of the focalized images onscreen, the weapon' scope and the portable video camera, are also embedded within the scene itself. Aligning the gun with the camera, Paul Virilio equates the vernacular of "capturing" an image on camera with that of taking aim through the optical scope of a 
weapon: "Before attaining his target, a hunter or a warrior must always take aim, to align his target between the eyepiece and the sight of his weapon, exactly as a cameraman frames the subject that he is about to shoot" $(2002,53-4)$. Implicit within this act of "taking" an image, or a life, is the human agent and subject that reside on either side of the ocular lens.

Therefore, individual bodies are implicated within the machinery of war as much as optical technologies.

Human experiences are embedded within an authoritative, political system, and in diegetic photographs and other recorded media. Using the term "mirror-text" as a synonym for mise en abyme, Bal writes: "The mirror-text serves as directions for use: the embedded story contains a suggestion how the text should be read. Even in this case, the embedded text functions as a sign to the reader" $(1997,59)$. The embedded text is built out of the layers of fragmentary focalizations which offer directions in which to look. In The Hurt Locker and Generation Kill the human agent utilizes the act of looking (even if it is mediated through digital apparatuses), and this act belongs to a "bigger picture," as a component of the biopolitical machine: "As troops come into violent contact with each other, they viciously give body to the political struggle between two opposing armed forces" (Bronfen 2012, 107). Bruce Bennett and Bülent Diken (2011) make a case for The Hurt Locker as a representation of biopolitics where characters are "locked into their (biopolitical) bodies" and Iraqis "appear in the film as bare life, life that can be killed with impunity" $(169,179)$. The contact between bodies, the identification of bodies, and the removal of bodies is often mediated, and even facilitated by diegetic optical apparatuses used on the ground, and embedded onscreen.

In the episode "The Cradle of Civilization" (2008), in Generation Kill, we are shown a sequence where the convoy of Humvees travels along a road. The camera pans along the roadside, spliced with close-ups of the soldiers' faces. When the camera moves, the "look" of the soldier is implicated: the camera captures what the soldier sees. This is an example of 
focalization where the viewer is witness to the direction of the focalizing soldiers' look, which is aimed towards the bodies and burnt out vehicles at the side of the road. The camera moves, but maintains its sight on the focalized object: the angle of viewing changes, but the object of focus remains the same. The US soldiers, and the direction of their look is what guides the representation of this Iraqi landscape. The soldiers give "body" to the US invasion of Iraq as we witness their movement across Iraq's terrain, and their look is directed towards Iraqis who are often represented as dead, or nearly dead.

In this same sequence, the look directed by the soldiers is also mediated through digital and mechanical optical apparatuses. In another panning optical frame, the viewer is shown a dead female whose legs have been cut off which "Scribe" then takes a picture of. While the photograph is not seen in and of itself, the action of taking a photograph is a form of embedding that appears recursive: we are shown the action that has not only facilitated the act of looking, but will produce a record, an image, that will be disseminated, and will extend beyond this moment. "Scribe's" act of focalization creates a recording, or re-representation that can be viewed again and again, in which a fragment of the scene on the ground is captured by optical apparatus, and may be focalized outside of its primary diegetic context. Moments later, one of the soldiers captures the same body on a digital video camera. The cinematographic camera pans back to the female victim and the overlay of the digital readout from the video camera is shown onscreen. This action of digital recording that is performed by the soldier represents an instance of mise en abyme that reiterates the space that is being travelled through. The focus on a dead body by the naked eye, the cinematographic camera, the analogue camera, and the video camera, with repeated "looks" directed towards the same scene, and the preoccupation of the focalized object (the dead girl) by the focalizers (the soldiers), indicates the inanimate bare life of the Iraqis as compared to the soldiers. 
We can go further, and distinguish the "gaze" from the "look." Bal identifies the "gaze" as "a fixed and fixating, colonizing mode of looking - a look that objectifies, appropriates, disempowers, and even, possibly, violates" $(2012,35)$. The fixated gaze is what we witness in this sequence in Generation Kill. The camera pans back to the dead body, adjusting the direction of its look to maintain its sights on the focalized object, regardless of the change in the focalizers' position. Further still, the digital apparatuses that capture the focalized body record, preserve, and reiterate the "look" which is repeatedly directed towards the dead body which, paradoxically, embodies bare life. This combination of lingering attention, embedded media, and reiteration appropriates the dead body and locates the power within the "look" of the chief focalizers: the soldiers (and embedded journalist).

The soldiers and their targets belong to a biopolitical machine, and are components of this figurative operating system. As Sergeant Brad Colbert (Alexander Skarsgård) puts it in the episode “A Burning Dog” (2008) in Generation Kill: "We aren't being warriors out here. They're using us as machine operators." The machine operator, or soldier, and the optical field that they receive (or generate) is amplified by military machineries beyond the video camera. Citing surveillance screens and tele-communications, Virilio argues that "alongside the 'war machine', there has always existed an ocular (and later optical and electro-optical) 'watching machine"” $(1992,3)$. The warriors/machine operators in Generation Kill are supported by an array of ocular technologies, including night vision goggles (NVGs). Used in Baghdad during the Iraq War, the optical feedback from the NVGs made the people captured by this technology look "interchangeable" and "dehumanised spectres in the night-goggled eyes of their occupiers" (Soltysik Monnet 2016, 129). An extended firefight in the episode "A Burning Dog," uses the filter of NVGs and weapons' scopes to represent the action onscreen. It offers another representation of bare life: the troops give body to the war, and are implicit within a biopolitical field, but the Iraqis are, to some extent, non-corporeal. Filtered through 
the NVGs, the Iraqis are literally spectres, indistinct white blobs ghosting across the screen, and observed through the colonizing gaze, filtered through the scope of their weapon.

Virilio establishes that " $\mathrm{t}] \mathrm{he}$ function of the weapon is first of all the function of the eye: sighting" $(2002,53)$. The scope, when aligned with the cinematographer's camera, renders an onscreen representation of fragmentary focalization. The scope magnifies the scene in an example of an "extreme close-up" and facilitates an omnipresent gaze towards an unseeing target in a violating, disempowering, and colonizing look. The scope points in a specific direction where the focalizer watches the focalized target, who he intends to eliminate. We are often not offered the target's perspective: as bare life his focalization is not what the cinematographic camera is interested in. Meanwhile, the cinematographic camera often captures the exact vision of the focalizing soldier. The focalized subject is not just represented, but targeted, and framed through the action of focalization that is filtered through the sight of a weapon. In Generation Kill and The Hurt Locker this is occasionally made explicit with the inclusion of the dark frame around the onscreen view of the scene. Framing the cinematographic scene with the scope informs us of the apparatus being used to facilitate the act of watching.

In The Hurt Locker, in a scene where the soldiers are pinned down in the desert by shooters lodged in a small structure, the weapon's scope is used in a number of interesting ways. The Iraqis actually take on the role of focalizer/shooter, with the frame of the scope included in some instances. However, even in these scenes, the British and American soldiers" "look" is privileged. The Iraqi who is focalizing through the weapon's scope does no more than sight the target (Ralph Fiennes), while the muzzle flash of the Iraqi's gun and the soldier's subsequent death is captured onscreen from within the American and British soldiers' field of vision. In contrast, when the Iraqi is shot by Sergeant TJ Sanborn (Anthony Mackie) the direction of focalization in relation to the kill-shot is notably driven by the 
fixating look of the American. When Sanborn sights the target, the grainy, zoomed-in camera actively searches the area. We are shown Sanborn looking through his scope and firing the shot before the cinematographic camera then captures the kill-shot from the same position as the focalizer's directed look. The Iraqis' deaths are watched onscreen, and their bodies are even revisited throughout the course of the scene, with the camera returning to linger on the body of the dead shooter in the window multiple times. The act of killing is enfolded within the act of looking. Towards the end of this sequence the cinematographic camera offers a close-up which faces Sanborn head on. Sanborn is looking through his weapon's scope, and his eye is seen, magnified, through the lens. Sight and weapon become fully integrated: Sanborn is the human agent whose eye is the mechanism of focalization which is necessary for identifying the target and, therefore, the ability to use the weapon accurately. The shooter is the focalizer, and the focalizer is part of the optical machinery.

This entire sequence is made out of fragmentary focalizations which are composited within an embedded "extreme close-up." The stillness, haziness, and blanched out landscape compounds the isolation of the scene and the distance marked between both combative parties, who are pinned down by each other's gunfire. It is an isolating moment, one that is constructed out of an exchanging of looks; looks which are linked to gunfire. David LaRocca suggests that there is an "equivalency between the camera and the gun: how they share sightlines; how they embody a point of view from which to take a picture or take a life" $(2014,9)$. In this sequence, the cinematographic camera captures multiple instances of life being taken, from both sides of the battlefield, but the predominant field of vision lies with the British and American soldiers. The camera takes pictures of life being taken from both sides of the battle, but the chief focalizer is the American soldiers.

\section{Recording War, Watching War, Watching Recordings}


We have so far seen the camera operating on two levels in the cinematographic texts looked at: first, the embedded video camera captures the action on the ground directed by the soldieras-focalizer; second, the cinematographic camera works in tandem or equivalence with the sights of a weapon. There is an additional level at work wherein digitally recorded footage of the Iraq War is used for the purposes of disseminating intelligence. Virilio identifies that, in war, there has been produced "invisible weapons that make things visible - radar, sonar, and the high-definition camera of spy satellites" $(1992,71)$. However, recorded footage can also be used to make visible, and make accountable, the actions of war to the civilian public.

The amateur video recording that we see in Generation Kill represents what Stacey Peebles identifies as "digital vérité" $(2014,135)$. She argues that this approach is used in films about the Iraq War to "emphasize that it's possible, and even necessary, to see more of war than is allowed by such wide-angle perspectives as are employed by the mainstream media” $(2014,135)$. Diegetic weapon's scopes and “digital vérité” are apparatuses of focalization that capture only a limited visualization of the "bigger picture." However, by the nature of their diegetic and embedded formats, these focalizations also make up that same "bigger picture" which is perpetrated by the mainstream (corporate media, the Pentagon, etc.). In "The Cradle of Civilisation" in Generation Kill, one of the soldiers catches an explosion onscreen, to which the driver of the Humvee excitedly exclaims: "CNN would definitely pay for drama like that." This arbitrary reference to CNN, a major news media corporation that will both air and pay money for the recorded content, implies the commercialization and the public reach that amateur filmed footage garners. This, and similar references made towards film being posted to YouTube in The Hurt Locker, suggests that the "digital vérité" is embedded not just within the cinematographic frame, but also in other forms of media. Footage, which consists of fragmentary focalizations, capturing a rather literal "extreme close-ups" from the ground, is used to construct a "bigger picture" for the 
viewing public, to meet the expectations of network ratings, and/or to subvert political statements.

With the use of digital recording cameras by soldiers at the front " $[\mathrm{t}]$ he information front is no longer confined to traditional mass media but extended to an increasingly porous and fast global communication space" (Andén-Papadopoulous 2009, 18). This porous space is composited out of a patchwork of recorded and reported fragmentary focalizations, which generate these images in reference to a wider frame, one which implicates a politicized “bigger picture.” Speaking before the US Senate Armed Service Committee in 2004, Donald Rumsfeld, Secretary for Defence (2001 - 2006), responded to the scandal where photographs were released of tortured and abused Iraqi prisoners at Abu Ghraib:

We're functioning... in the information age, where people are running around with digital cameras and taking these unbelievable photographs and then passing them off, against the law, to the media, to our surprise, when they had not even arrived in the Pentagon ("Rumsfeld Testifies", 4). ${ }^{1}$

Rumsfeld implies that this method of amateur digital imaging is an illicit representation that exists outside but is also simultaneously "embedded" within the "official" message. The photographs from Abu Ghraib, and the digital recordings of events on the ground in Iraq, are examples of fragmentary focalizations that are part of the collaborative mechanism of the “information age." As "embedded" focalizations, these recordings shed light from within the frame of the official message, but also beyond it. The "extreme close-ups" implicate a "bigger picture" by adding to it, even arguing with it. Thus a wider debate between framesand the dead, tortured, and/or armed bodies captured within them-is generated.

Also in response to the photographs released as part of the Abu Ghraib scandal, Susan Sontag wrote in New York Times Magazine (2004) that: “A war, an occupation, is inevitably a huge tapestry of actions. What makes some actions representative and others not? The issue 
is not whether the torture was done by individuals... but whether it was systematic.

Authorized. Condoned." Sontag's use of the term "tapestry of actions" is a useful phrase which can be used to indicate the ways through which fragmentary focalizations collect together, each one an embedded narrative (or optical view) that, as "extreme close-ups," belong to part of a "bigger picture." Sontag argues that individual actions are part of a "systematic" process: the mechanised allegory locates these individual acts by human agents as constituting part of a larger machine. Embedded optical focalizations are nested in a wider operative system: the acts "captured" through digital apparatuses introduce frames that exist both within and outside of the image. The observer's and the actor's roles are collapsed as the "extreme close-up" becomes but one part of the wider debate, and vice versa. The images are even embedded in Rumsfeld's testimony: without these images there would be no testimony given, and without the wider system (the Pentagon) represented in Rumsfeld's speech, the acts of torture captured by these photographs would not have occurred. Here, we can see how the "digital vérité" embedded in representations of the Iraq War is part of a recursive structure of mise en abyme. It is within this contextual framework of the discursive fields of politics and media that the action of focalization functions in Generation Kill and The Hurt Locker.

The embedded "digital vérité" in these cinematographic texts are built out of the rising use of optical machinery (or digital apparatuses) by soldiers to record images not just for the purpose of shooting to kill, but shooting to show what is happening. The use of "digital vérité" as a technique in the making of films on the Iraq War is influenced, in part, by this rising use of cam-recorders by soldiers. Garrett Stewart is somewhat critical about this cinematographic technique, and suggests that "our contemporary wars on film are hampered by the very ethos of optical recording" $(2014,128)$. In his article, "Digital Fatigue: Imaging War in Recent American Film," he states that he feels that these kind of ocular techniques 
work at the expense of strong dramatic narrative, with choreographed epic battles conquering beachheads and defending fortresses being swapped out for fragmented, random, and chaotic scenes of violence $(2009,45)$. For Stewart, the image becomes more relevant than the narrative in these instances, where "the graininess of the image, infrared or video, must stand in for the true grittiness of the mission" $(2009,47)$.

Throughout this article, I have identified ways in which focalization implies a narrative position through visual means, within these same fragmented, blinkered scenes that Stewart considers detrimental. In her own response to Stewart, Peebles argues that "digital vérité" is necessary in films on the Iraq War "to see more of war than is allowed by such wide-angle perspective as are employed by the mainstream media, the military" $(2014,135)$. These fragmentary focalizations, in the register of "digital vérité," are "extreme close-ups" that offer a "look" that works outside of those attempting to administrate a mainstream perspective (for example, outside of the Pentagon's formal message). These fragmentary focalizations may, of course, end up in the mainstream, as the military driver's comment about CNN implies in Generation Kill. However, the point remains that the embedded look, or embedded recording, captures a focalization that is only possible when the soldier is not just the focalizer in the cinematographic scene, but is also holding the camera. While the dramatic storytelling of grandiose battles to take Omaha beach, as in the opening of Saving Private Ryan, might be lost in these smaller moments of fragmentary focalization, these instances of looking/recording do, as Stewart acknowledges, reflect the action that is happening now, filled with "random checkpoint suicides, grenade and mortar ambushes in blind alleys, frantic house searches, and impromptu firefights" $(2009,45)$. Importantly, “digital vérité" does not just implicate a "bigger picture," but also performs a personal narrative act. 
With portable digital recorders, "soldiers, journalists, and insurgents can now create the movie of the war in realtime" (Daly, 2009, 173). What is significant to note here is that it is not just the US soldiers, but also the insurgents that make use of digital recording equipment. The US soldiers deploy optics as part of their mechanized apparatuses in war, but this goes both ways, and these soldiers are also subject to being watched. In a sequence earlier on in The Hurt Locker, James disarms a bomb located inside a car outside of the UN building while Sanborn and Specialist Owen Eldridge (Brian Geraghty) form a protective perimeter. It is during this scene that we see an example of a video camera being used outside of the soldiers' control, in which they become the focalized subjects of a cam-recorder used by an Iraqi. There are a few instances where the cinematographic camera takes on the Iraqi focalizer's "look," but, for the most part, we witness how these soldiers respond to being the focalized subject of the diegetic video camera.

At one point, the scene features a series of embedded frames; a mise en abyme that illustrates a moment of compounded ocular apparatuses and simultaneous focalizations. The cinematographic image is framed by the circular scope of Eldridge's weapon, and at the centre of his directed optical view is captured an image of an Iraqi pointing his camera directly at Eldridge, essentially directing the look back through the scope. Here we have an instance that collapses the two optical scopes onto one another within the cinematographic camera: two embedded, diegetic ocular apparatuses. The focalizer (Eldridge) focalizes the focalized subject (the Iraqi cameraman) who is, in turn, also a focalizer, directing his look towards Eldridge as the focalized subject. In these embedded practices of focalization through optical apparatuses, we see what we have been saying all along: that the camera and the gun operate with the same function, that of sight and sighting. Of course, the scene is still first, and foremost, focalized through the look of the US military. The Iraqi is shown to be 
practicing an act of focalization, but the weapon's scope makes up the primary frame and we see through Eldridge's eyes, not the Iraqi's.

Despite not being the primary focalizer, whose look is mediated directly through the cinematographic camera, when Eldridge nervously states that "[h]e's pointing the fucking thing right at me," he identifies his position as the focalized subject that the Iraqis' look (and camera scope) is directed towards. Being the focalized subject within the warzone is unnerving for the soldiers involved: there is a feeling of threat established by being trapped from without. Sanborn's comment, which is spoken after the camera pans to show a number of men watching the scene from their windows and balconies, that "[w]e've got a lot of eyes on us James," feels somewhat reminiscent of Jeremy Bentham's model of the Panopticon that Michel Foucault cites in Discipline and Punish: The Birth of the Prison, wherein "[v]isibility is a trap" $(1977,200)$. In this environment, optical technologies are compounded with weaponry and also with the ability to perceive the battlefield and incoming threat. Therefore, visibility is a threat when you are the visible target being watched by a focalizer who has the potential to be your enemy.

There is another risk to being the focalized subjects of a recording. The Panopticon is an "architectural and optical system: it is in fact a figure of political technology" (Foucault 1977, 205). The surveillance implicated in the system of the Panopticon works as part of a system of power relations that establishes control and discipline over the focalized subject(s). In this scene from The Hurt Locker, the Iraqi cameraman is the focalizer whose act of watching and, more importantly, recording, establishes a relationship of control. Eldridge's nervous comment that the cameraman is "getting ready to put me on YouTube" indicates that the watcher is not merely the man holding the camera, but also the audience that will potentially view the clip online. When Eldridge asks what he should do about the cameraman, Sanborn replies: "Be smart, make a good decision." This comment about making the "good 
decision" is not merely about the morals and ethics of the individual, but also about how the action played out will be judged by the viewing public. Immediately following on from a suggestion that the recorded footage may be aired, the instruction to do the right thing is also a warning. The use of "[d]igital production tools, coupled with a user-friendly medium for dissemination provides material that is raw and unfiltered by the Pentagon" (Smith and McDonald 2011, 308). This footage, whether it is uploaded by soldiers, Iraqi civilians, or insurgents, makes those people who are recorded accountable. It was the images of the abused prisoners at Abu Ghraib prison that implicated the soldiers and politicians involved to both the public and the courts. With recorded video footage, which captures instances of torture or which focalizes the taking of a life, becoming more readily available to the public, the soldiers who are focalized by these apparatuses are accountable as individuals within a wider operating system.

In Generation Kill, the recording video camera is present throughout. Soldiers carry the portable recording devices on their person, and recorded footage is occasionally shown onscreen, overlaid with the digital readout of the viewfinder. At the conclusion of the series, in the final scene of "Bomb in the Garden" these recordings are shown to us again as a home movie made at war. The various recordings have been edited together and are displayed on a laptop screen for the soldiers of the Marine Recon Unit and for the viewers of the mini-series to watch. Kristen Daly states that, "with mobile media and instant distribution, soldiers are the actors, authors, extras, and objects of these cinematic realities" $(2009,173)$. The soldiers become both the focalized and focalizers to their own actions in another example of embedded, recursive media, or mise en abyme. This occurs twice over: the soldier as cameraman focalizes the actions of his fellow comrades (the focalized), and then later, when they watch the edited footage, the soldiers become the focalizers of themselves as they are represented onscreen as focalized subjects. The soldiers are both agent and subject, and "the 
waging and representing of war are enmeshed almost to the point of being inseparable" (Andén-Papadopoulous, 2009, 20).

The recursive structure of this recorded footage is further emphasized in that the scenes that were caught on camera earlier in the series are shown once more in the edited home movie. Watching the edited recording is in fact a re-watching for both the soldiers and the viewers of the mini-series. Just as the weapon and the camera are collapsed through their shared dependence on the viewfinder, the focalizer and the focalized also become compounded. Fragmentary focalizations do not exist in a vacuum, or even as patchwork. Rather, they are layered, palimpsestic frames that intersect with and exist within one another: a composite of "extreme close-ups" that are recursive, repeated, inverted, and reverted, looked at, looked back at, edited, leaked, disseminated, sold, and embedded within the socalled "bigger picture."

\section{Conclusion}

Operated by human individuals, who sight—or focalize — their target, guns, drones, and missiles make up the machineries of war. Their use is facilitated by continually advancing ocular and optical viewfinders and recording equipment. The moral and political mire associated with the optical and recording devices attached to weaponry has been further explored in more recent cinematography, reaching beyond the context of the Iraq War considered in this article, in, for example, the film Eye In The Sky (2015) and in Season Four of $\underline{\text { Homeland }}$ (2011 - Present). While the scope of the gun has been the predominant focus of this article in terms of weaponry, aerial assaults also make extensive use of optical devices that focalize targets. Significantly, they compound the recording technologies explored through the medium of cam-recorders in this article, with the purpose of focalizing a target, which has been associated with the weapon's scope. 
For instance, in the Homeland episode "The Drone Queen" (2014), when an airstrike is ordered on a building believed to house the target Haissam Haqqani, the action is captured onscreen by the live-feed aerial recording. The screen is embedded into the cinematographic frame, with Carrie Mathison (Claire Danes) and her colleague watching in the foreground of the scene. The audience literally looks over their shoulders to view the action being recorded by the live-feed: the audience become complicit focalizers. This singular piece of action, watched from afar via a recording in a windowless room, perpetrates an "extreme close-up." However, as I have argued, fragmentary focalizations (such as the aerial footage of the airstrike) intersect with others, composing a "bigger picture." In “The Drone Queen” the aerial footage used by the US officers and agents intersects with an amateur phone recording taken by a survivor of the missile strike, Aayan Ibrahim (Suraj Sharma). This recording reveals that the target building was hosting a wedding, and shows the revels of the celebrating guests before ending with a flash, marking the point at which the missile hits. The video focalizes the action from a different direction, one in which the targets are still the focalized subjects, but where focus is not on the strike itself, but on the casualties - the collateral — that it will make.

In comparison to the often distant or desensitizing recordings discussed earlier in this article, captured by aerial shots, cam-recordings, and NVGs, this example of amateur footage is intended to humanize the focalized subjects. In "The Drone Queen" the video footage is shown through diegetic media, and the recording is disseminated on YouTube. Saul Berenson (Mandy Patinkin) watches the YouTube video, entitled "American Missile Strike on Wedding," and focalizes the celebrations and missile strike not through the distant aerial footage used by the US operatives, but through the eyes (or lens) of Aayan. The two instances of footage - the aerial and the amateur phone recording — intersect, capturing, and focalizing, the same moment from different angles. These "extreme close-ups," together expand and 
build a "bigger picture," with the viral YouTube video extending this further, wherein the dissemination of the phone recording to an international, public audience fulfils the warning given by Sanborn to Eldridge in The Hurt Locker: ocular recording technologies when transmitted outside of the Pentagon's filters, brings US military and defence operatives under public scrutiny. As CIA Director Lockhart (Tracy Letts) puts it to Carrie in the following episode, "Trylon and Perisphere" (2014): "The word is accountability." Advancing on the arguments conducted in relation to The Hurt Locker and Generation Kill, as examples of cinematography on the Iraq War, "The Drone Queen" posits that the human individual is at the centre of ocular and optical technologies: as operators and focalizers, and as the target and the focalized. It is through intersecting, palimpsestic frames, or focalizations, that US operators are themselves focalized: by their targets, by governmental oversight, and by the public.

Both The Hurt Locker and Generation Kill offer fragmentary focalizations that exist within a wider frame and discourse. These cinematographic texts emulate recursive narrative structures, which results in an effect of embedding, or mise en abyme. This narrative technique, alongside the use of diegetic ocular apparatuses, collapses and compounds the identity of the focalizer and focalized... the watcher and watched. This article has examined the ways through which the "look" has been deployed onscreen. Optical apparatuses, such as portable cameras, viewfinders, and weapons scopes, facilitate the act of watching both in terms of diegetic and non-diegetic viewing bodies. These ocular devices frame and magnify images, as well as record, with the potential to disseminate, the images that are captured.

Ocular technologies facilitate war, and are part of the biopolitical mechanism of war. Ocular technologies are deployed as part of weapons usage: bodies use scopes and digital imaging, and bodies are caught on camera, and in the crosshairs. Optical devices do not just facilitate the movement of the "look," but also the bodies on the ground. In The Hurt Locker 
and Generation Kill, the Iraq War is rendered onscreen by the same diegetic ocular apparatuses that are themselves part of the compositional make-up of the war. I have examined the different registers through which the "look" may be directed or deployed onscreen. What is significant about these often diegetic tools is that they may capture the "extreme close-up," but they also insinuate that someone is watching, and even disseminating the images captured. The actual act of capturing the image through different ocular apparatuses implicates a "bigger picture" of a larger discursive field in politics and in the media. The "bigger picture" is porous and constructed out of manifold fragmentary focalizations, and is built out of recursive, embedded, and ultimately palimpsestic visual renditions of war. But even more disturbingly, and what becomes abundantly clear in an examination of the ways in which actions are captured onscreen in The Hurt Locker and Generation Kill, is that diegetic optical apparatuses such as weapon's scopes and recording technologies are not merely facilitating acts of focalization, but also the act of taking life. 


\section{Notes}

\footnotetext{
${ }^{1}$ Abu Ghraib in Baghdad was used as a detention facility during the Iraq War where coalition forces imprisoned and interrogated prisoners of war. The scandal that revealed the abuse of these prisoners broke in 2003 when Amnesty International reported on what was happening, and photographs of prisoners and soldiers were disseminated by the media.
} 


\section{References}

“A Burning Dog.” DISC. Generation Kill. Directed by Simon Cellan Jones. 2008. New York: Home Box Office.

American Sniper. Directed by Clint Eastwood. 2014. CA: Burbank: Warner Home Video. Andén-Papadopoulos, Kari. 2009. “US Soldiers Imaging the Iraq War on YouTube.” Popular Communication 7 (1): 17-27. doi: 10.1080/15405700802584304.

Bal, Mieke. 2012. Travelling Concepts in the Humanities: A Rough Guide. Toronto: University of Toronto Press.

Bal, Mieke. 1997. Narratology: Introduction to the Theory of Narrative. $2^{\text {nd }}$ ed. Toronto: University of Toronto Press.

Bennett, Bruce, and Bülent Diken. 2011. "The Hurt Locker: Cinematic Addiction, "Critique," and The War on Terror." Cultural Politics 7 (2): 165-88. doi: $10.2752 / 175174311 X 12971799875861$

"Bomb in the Garden." DISC. Generation Kill. Directed by Susanna White. 2008. New York: Home Box Office.

Bronfen, Elisabeth. 2012. Specters of War: Hollywood's Engagement with Military Conflict. New Brunswick, NJ: Rutgers University Press. http://www.jstor.org.ezproxy.lancs.ac.uk/stable/j.ctt5hj3rx.

Bryson, Norman. 2001. "Introduction.” In Looking in: The art of viewing, Mieke Bal, 1-39. Australia et al.: G + B Arts International.

Daly, Kristen. 2009. "Remediated War in Iraq.” Peace Review: A Journal of Social Justice 21 (2): 171-81. doi: 10.1080/10402650902877401.

Eye in the Sky. Directed by Gavin Hood. 2005. Toronto: Entertainment One. 
Foucault, Michel. (1975) 1977. Discipline and Punish: The Birth of the Prison. Translated by Alan Sheridan. London: Allen Lane.

Generation Kill. Written by David Simon and Ed Burns. New York: Home Box Office, 2008. LaRocca, David. 2014. "Introduction: War Films and the Ineffability of War." In The Philosophy of War Films, edited by David LaRocca, 1-77. Kentucky: The University of Kentucky Press. http://www.jstor.org.ezproxy.lancs.ac.uk/stable/j.ctt12880b3.

McHale, Brian. 1987. Postmodernist Fiction. New York: Methuen.

Peebles, Stacey. 2014. “Lenses into War: Digital Vérité in Iraq War Films.” In The Philosophy of War Films, edited by David LaRocca, 133-54. Kentucky: The University of Kentucky Press. http://www.jstor.org.ezproxy.lancs.ac.uk/stable/j.ctt12880b3.

Porter, Patrick. 2009. Military Orientalism: Eastern War Through Western Eyes. London: Hurst \& Company.

"Rumsfeld Testifies Before Senate Armed Services Committee.” Washington Post Politics, 7 May 2004. Accessed 11 August 2016. http://www.washingtonpost.com/wpdyn/articles/A8575-2004May7.html

Saving Private Ryan. Directed by Steven Spielberg. 1998. Los Angeles: Paramount Pictures. Smith, Christina M., and Kelly M. McDonald. 2011. "The Mundane to the Memorial:

Circulating and Deliberating the War in Iraq Through Vernacular Soldier-Produced Videos." Critical Studies in Media Communication 28 (4): 292-313. doi: $10.1080 / 15295036.2011 .589031$.

Soltysik Monnet, Agnieszka. 2016. "Night Vision in Contemporary Horror Film.” In Digital Horror: Haunted Technologies, Network Panic and the Found Footage Phenomenon, edited by Linnie Blake and Xavier Aldana Reyes, 123-136. London: I. B. Tauris. 
Sontag, Susan. 2004. "Regarding the Torture of Others." New York Times Magazine, 23 May. Accessed 11 August 2016. http://www.nytimes.com/2004/05/23/magazine/regarding-the-torture-ofothers.html?_r=0

“Stay Frosty.” DISC. Generation Kill. Directed by Simon Cellan Jones. 2008. New York: Home Box Office.

Stewart, Garrett. 2014. "War Pictures: Digital Surveillance from Foreign Theater to Homeland Security Front." In The Philosophy of War Films, edited by David LaRocca, 107-31. Kentucky: The University of Kentucky Press. http://www.jstor.org.ezproxy.lancs.ac.uk/stable/j.ctt12880b3.

Stewart, Garrett. 2009. "Digital Fatigue: Imaging War in Recent American Film.” Film Quarterly 62 (4): 45-55. doi: 10.1525/fq.2009.62.4.45.

Taibbi, Matt. 2015. ““American Sniper’ Is Almost Too Dumb to Criticize.” Rolling Stone, 21 January 2015. Accessed 11 August 2016. http://www.rollingstone.com/politics/news/american-sniper-is-almost-too-dumb-tocriticize-20150121

“The Cradle of Civilization.” DISC. Generation Kill. Directed by Susanna White. 2008. New York: Home Box Office.

“The Drone Queen.” Homeland. Directed by Lesli Linka Glatter. 2014. Netflix. Accessed 1 June 2017. http://www.netflix.com.

The Hurt Locker. Directed by Kathryn Bigelow. 2008. CA: Santa Monica: Lions Gate Home Entertainment.

“Trylon and Perisphere.” Homeland. Directed by Keith Gordon. 2014. Netflix. Accessed 1 June 2017. http://www.netflix.com. 
Tumber, Howard, and Jerry Palmer. 2004. Media At War: The Iraq Crisis. London: SAGE Publications.

Virilio, Paul. (1991) 2002. Desert Screen: War at the Speed of Light. Translated by Michael Degener. London: Continuum.

Virilio, Paul. (1984) 1992. War and Cinema: The Logistics of Perception. Translated by Patrick Camiller. London: Verso. 